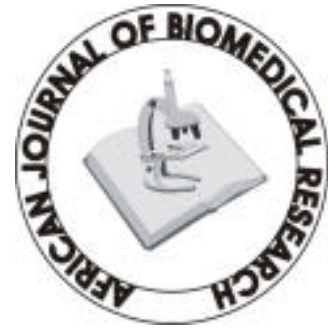

Full-text available at http://www.ajbrui.com

http://www.bioline.br/md

Received:

July, 2005

Accepted (Revised):

October, 2005

Published

January, 2006
Full Length Research Article

\section{Effect of Halofantrine Administration on some liver and heart enzymes in Healthy Human Volunteers}

\section{${ }^{1 *}$ Bassi PU, ${ }^{2}$ Buratai BL, ${ }^{2}$ Kuchali W}

Departments of Clinical Pharmacology/Therapeutics ${ }^{1}$ and Biochemistry ${ }^{2}$, University of Maiduguri. Maiduguri, Nigeria.

\section{ABSTRACT}

The effect of halofantrine on liver and the heart was evaluated in 15 healthy adult human volunteers (11 females and 4 males), after a single oral dose of halofantrine given to each volunteer. Blood samples were collected at predetermined time intervals and analysed for the various liver and heart enzyme activities \{Aspartateaminotransferase (AST), Alanineaminotransferase (ALT), Alkalinephosphatase(ALP),Creatine phosphokinase $(C K)$ and lactatedehydrogenase $(L D H)\}$, before and after drug administration. Halofantrine administration caused a steady increase in the activities of all the enzymes with a peak at the $8^{\text {th }}$ hour. These values were statistically significantly $(p<0.05)$ different from the base line $(0 \mathrm{hr})$ especially at the $8^{\text {th }}$ hour. The increase in enzyme activity corresponds to peak serum concentration of halofantrine as seen in earlier studies. It conclude that halofantine administration at therapeutic or higher doses could result in an increase in enzyme activities and since these vital organs, plays a significant role in halofantrine pharmacokinetics, may play a role in predicting halofantrine toxicity/and or effect. (Afr. J. Biomed. Res. 9: 31 - 35, 2006)

Keywords: Halofantrine, human, biochemistry, Hepato/Cardiotoxicity

**Correspondence: E-mail address: pubassi@yahoo.com; Tel: +2348034945067 


\section{INTRODUCTION}

The search for safe and effective anti malarial drug still remain a priority to health care givers in the sub-Saharan African, as malaria continues to threaten life through the bite of drug resistant parasite in the sub region (Fitch, 1983). More than two billion people (about $40 \%$ of the world population) in 100 countries are at risk of the disease (WHO, 1994). There are at least 300 million cases of acute malaria each year, most of whom are children under the age of 5 years. Other high risk groups include pregnant women, non-immune travellers/HIV patients, refugees, displaced persons, or labour forces entering into endemic areas (Phillips, 2001).Countries in tropical Africa bear the brunt of malaria, accounting for more then $90 \%$ of the 300 million cases of malaria. It is estimated to cost Africa more than 12 billion U.S dollars annually (Rathod et $\underline{\text { al }}$; 1997)

Malaria can however be adequately and promptly treated through drug therapy (Peters, 1998, Olumese 1998) and over the years, various antimalarial drugs have been produced; The first widely used antimalarial drugs in the treatment of malaria is Quinine from Peruvian bark that were originally sensitive to $P$. falciparum spp. (Rathod $\underline{\text { et }}$ al; 1997). However strains resistant to this and other anitimalarial drugs are now common (Warhurst, 2001, Salako et al 1987), hence the parasite is now able to multiply in the presence of the drugs (Chatterjee, 1976). The development of resistance to the various antimalarial drugs is causing a major draw back in the control of malaria (WHO, 1994).

Halofantrine, a phenanthrane-methanol, is highly effective drug for P.falciparum malaria (Ter Kule et al 1993) and remained effective in multi-drug resistant areas, has a simple dosage regimen and is relatively cheap, however consistent cardio toxicity reports has made its use on large scale difficult (Molta, 1995).moreover, most of the available options have their respective drawbacks, which is also a major considerable burden to the problem of drug resistance (WHO, 1994). Extensive work has been done to asses the cardiotoxicity effects of halofantrine both in healthy human volunteers and patients with malaria, (Sowounmi et al 1998, Margaretha B et al, Eric Monilun 1995), but one other area that needs evaluation is the hepatotoxicity of the drug, as this drug is metabolised in the liver (Robert et al; 1990) and therefore the liver carry a major burden of the effects of the drug.Enzymes have been used as effective tools in the diagnosis of various medical problems and they also serve as markers of hepatocellular damage (Afonja 1993 Ngana et al 1989, Briggs et al 1974). These enzymes are therefore likely to play a role in hepatic and cardiac toxicity. The study therefore evaluated, the role of cardiac and liver enzymes in the diagnosis of halofantrine toxicity, and also assessed the changes of these enzymes before and after administration of halofantrine to apparently healthy human volunteers as well as compared these changes before and after the administration of halofantrine to the volunteers.

\section{MATERIALS AND METHOD}

\section{Location of study}

The study was carried out in the department of clinical pharmacology and therapeutic laboratory college of Medical Sciences University of Maiduguri. Ethical clearance was obtained from the joint ethical committee of the UMTH/College of Medical Science University of Maiduguri before conducting the study.

\section{Chemical and Reagents}

Methylated Sprite, (Randox laboratories Ltd U.K),Buffer/glucose (Randox laboratory Ltd U.K),NADH kit (LD 526) (Randox Laboratories Ltd UK).Enzyme/Co enzyme/substrate - kit (Ck 110) (Randox Laboratories U.K), 2,4-dinitrophenylhydroazine- (Randox laboratories U.K).Distilled water- (Ben Medical laboratory, Maiduguri).Chromogenic substrate-(Randox Laboratories Ltd U.K).Sodium Hydroxide - Avondate Laboratory (supplies) and services Ltd Banbury Oxon England.

\section{Analytic equipment:}

Semi Automated Chemistry Analyser-ERBA. CHEM PRO Transaia bio-medicals Ltd MUMBDI.Centrifuge Machine (Health University II England). Water bath (series 12790/38 Old England

\section{Treatment of subjects:}

A total of 15 healthy adult human volunteers (4 male and 11 females) after obtaining a written consent, where recruited into the study after medical history taking and clinical assessment. The subjects were between the ages of 18 and 25 years with an average body weight of $45 \mathrm{~kg}$. None of the volunteers had been on any medication in the previous two weeks preceding the study. All volunteers were students of the University of Maiduguri who reside in the hostels of the same institution. They all gave their written consent to participate in the study. Full Blood count, Packed Cell Volume, Liver function Test were all, done as part of clinical assessment, subjects were fed and kept in the laboratory for the first 12 hours of the study. Subsequently they were allowed to go to hostel which is about $500 \mathrm{~m}$ from the study and reported everyday for assessment and sampling until the end of study. They were not allowed to engage in strenuous exercise or take other medication throughout the period of study. The analysis was carried out in Chemical pathology 
department of the University of Maiduguri teaching hospital.

\section{Drug administration}

All subjects were administered a single dose of $500 \mathrm{mg}$ of halofantrine hydrochoride in the form of tablet (2 tablets of halfanR) Smithkline Beecham, Lagos, Nigeria) with 100ml of water.

\section{Sample collection.}

Blood (5ml) was collected at the enrolment from all subjects through venipuncture. The blood sample was taken for the determination of Full Blood Count and differentials, Packed Cell Volume and Liver Function Test. This served as a baseline data (i.e. 0 hour reading, control), before the administration of the drugs; it was also used for clinical assessment. The

Blood samples were taken at predetermined intervals of 1 , $3,6,8,12,24,48,72$, and 168 hours after the administration of the drugs. These samples were placed in a centrifuge tubes and centrifuged at $500 \mathrm{rpm}$ for $15 \mathrm{~min}$ in a centrifuge tubes to obtain serum, which was placed in a plain tubes well labelled bottles and were stored frozen at $-20^{\circ} \mathrm{C}$ until analysis. Samples used for haematological analysis i.e. Packed Cell Volume, Full Blood Count were put into EDTA bottles. The serum colleted was analysed for the following enzymes; ALP, ALT, AST, LDH and CK at Chemical pathology Dept. University of Maiduguri Teaching Hospital.

\section{Data Analysis}

Data from Case Report Form were entered into IBM compatible PC EPI -INFO software. Data analysis was performed using the EPI-INFO, and SPSS. Data were compared using the student's t-test while means are expressed as mean standard deviation $( \pm S D)$. P values of less than 0.05 were taken as statistically significant

\section{RESULTS}

Fifteen healthy adult volunteers were given a single dose $(500 \mathrm{mg})$ of halofantrine hydrochloride and their blood was taken at predetermined time intervals ranging from 0-168 hours. All the volunteers were monitored clinically through out the study. They all tolerated the study drug and there were no history of adverse drug reaction.

The data are presented on Table 2 as mean plus minus standard deviations $( \pm \mathrm{SD})$. For the 0 hour parameters, the values are as follows AST 7.7 \pm 2.0 (range 7-13), ALT 6.1 \pm 1.9 (range 4.0 -12), ALP 35.3 \pm 7.0 (range 23

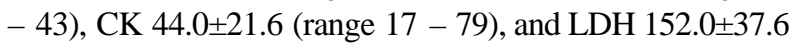
(range $92-120$ ) respectively. All these values falls within a normal laboratory reference range for adults.

\section{Table 1}

Anthropometric and Baseline parameters before administration of study drugs.

\begin{tabular}{llll}
\hline Parameter & Mean \pm SD & \multicolumn{2}{c}{ Range } \\
\cline { 2 - 4 } & & Min & Max \\
\hline Age $(\mathrm{yrs})$ & $22.20 \pm 2.04$ & 18 & 25 \\
\hline Weight $(\mathrm{g})$ & $47.23 \pm 5.39$ & 38.5 & 60 \\
\hline Pulse rate/min & $72.73 \pm 11.07$ & 52 & 91 \\
\hline Systolic B.P & $109.23 \pm 13.00$ & 90 & 130 \\
\hline Diastolic B.P & $74.40 \pm 8.72$ & 60 & 90 \\
\hline Body Temp $\left({ }^{\circ} \mathrm{C}\right)$ & $36.02 \pm 0.74$ & 34.8 & 37.5 \\
\hline $\begin{array}{l}\text { TWBC Count } \\
\left(10^{3} / \mathrm{mm}^{3}\right)\end{array}$ & $6260 \pm 492.94$ & 3600 & 10000 \\
\hline PCV $(\%)$ & $45.73 \pm 5.48$ & 37 & 52 \\
\hline
\end{tabular}

\section{Table 2:}

Profile of the enzyme activity of the 15 volunteers before and after drug administration of $500 \mathrm{mg}$ Halofantrine hydrochloride.

\begin{tabular}{|c|c|c|c|c|c|c|c|c|c|c|}
\hline $\begin{array}{l}\text { Hours/ } \\
\text { Enzymes }\end{array}$ & 0 & 1 & 3 & 6 & 8 & 12 & 24 & 48 & 72 & 168 \\
\hline AST & $\begin{array}{l}7.7 \pm \\
2.0^{\mathrm{a}}\end{array}$ & $\begin{array}{l}10 . \pm \\
2.3^{\mathrm{a}}\end{array}$ & $\begin{array}{l}11.5 \pm \\
0.0-^{b}\end{array}$ & $\begin{array}{l}11.7 \pm \\
2.0^{\mathrm{a}} \\
\end{array}$ & $\begin{array}{l}16.7 \pm \\
2.7^{\mathrm{b}}\end{array}$ & $\begin{array}{l}15.8 \pm \\
4.7^{b}\end{array}$ & $\begin{array}{l}8.7 \pm \\
1.9^{\mathrm{a}}\end{array}$ & $\begin{array}{l}8.8 \pm \\
2.9^{\mathrm{a}} \\
\end{array}$ & $\begin{array}{l}9.7 \pm \\
2.5^{\mathrm{a}} \\
\end{array}$ & $\begin{array}{l}8.6 \pm \\
2.3^{\mathrm{a}} \\
\end{array}$ \\
\hline ALT & $\begin{array}{l}6.1 \pm \\
1.9^{\mathrm{a}}\end{array}$ & $\begin{array}{l}6.7 \pm \\
1.4^{\mathrm{a}}\end{array}$ & $\begin{array}{l}5.0 \\
\pm 1.8^{\mathrm{a}}\end{array}$ & $5.2 \pm 2.0^{\mathrm{a}}$ & $\begin{array}{l}7.8 \pm \\
1.9^{\mathrm{b}}\end{array}$ & $\begin{array}{l}6.0 \pm \\
3.1^{\mathrm{a}}\end{array}$ & $\begin{array}{l}5.4 \pm \\
3.0^{\mathrm{a}}\end{array}$ & $4.5 \pm 2.0^{\mathrm{a}}$ & $5.3 \pm 1.9^{a}$ & $\begin{array}{l}4.6 \pm \\
1.4^{\mathrm{a}}\end{array}$ \\
\hline ALP & $\begin{array}{l}35.3 \pm \\
7.0^{\mathrm{a}} \\
\end{array}$ & $\begin{array}{l}29.0 \pm \\
3.5^{\mathrm{a}}\end{array}$ & $\begin{array}{l}33.8 \pm \\
5.0^{\mathrm{a}}\end{array}$ & $\begin{array}{l}35.6 \\
\pm 12.3^{\mathrm{a}}\end{array}$ & $\begin{array}{l}40.8 \pm \\
18.1^{\mathrm{b}}\end{array}$ & $\begin{array}{l}25.6 \pm \\
5.2^{\mathrm{a}}\end{array}$ & $\begin{array}{l}31.1 \pm \\
5.8^{\mathrm{a}} \\
\end{array}$ & $\begin{array}{l}25.5 \pm 44 \\
\mathrm{a}\end{array}$ & $\underset{\mathrm{a}}{31.15 .8}$ & $\begin{array}{l}25.3 \pm \\
4.6^{\mathrm{b}}\end{array}$ \\
\hline CK & $\begin{array}{l}44.0 \pm \\
21.6^{\mathrm{a}} \\
\end{array}$ & $\begin{array}{l}41.3 \pm \\
21.0^{\mathrm{a}} \\
\end{array}$ & $\begin{array}{l}40.2 \pm \\
16^{\mathrm{a}} \\
\end{array}$ & $\begin{array}{l}51.3 \\
\pm 15.0^{\mathrm{a}} \\
\end{array}$ & $\begin{array}{l}63.8 \pm \\
23.7^{b} \\
\end{array}$ & $\begin{array}{l}61.8 \pm \\
23.7^{\mathrm{b}} \\
\end{array}$ & $\begin{array}{l}58.3 \pm \\
23.4^{\mathrm{a}} \\
\end{array}$ & $\begin{array}{l}54.2 \\
\pm 23.2^{\mathrm{a}} \\
\end{array}$ & $\begin{array}{l}47.2 \pm \\
22.7^{\mathrm{a}} \\
\end{array}$ & $\begin{array}{l}36.4 \pm \\
16.2^{\mathrm{a}} \\
\end{array}$ \\
\hline $\mathrm{LDH}$ & $\begin{array}{l}151.0 \pm \\
37.6^{\mathrm{a}} \\
\end{array}$ & $\begin{array}{l}140.0 \pm \\
39.4^{\mathrm{a}} \\
\end{array}$ & $\begin{array}{l}146.6 \\
\pm 4.1 \\
\end{array}$ & $\begin{array}{l}184.7 \pm \\
53.0^{\mathrm{a}} \\
\end{array}$ & $\begin{array}{l}198.7 \pm \\
70^{\mathrm{b}} \\
\end{array}$ & $\begin{array}{l}145.7 \pm \\
39.7^{\mathrm{a}} \\
\end{array}$ & $\begin{array}{l}115.3 \pm \\
17.9^{\mathrm{b}} \\
\end{array}$ & $\begin{array}{l}139.2 \pm \\
44.0^{\mathrm{a}} \\
\end{array}$ & $\begin{array}{l}155.5 \pm \\
42.1^{\mathrm{a}} \\
\end{array}$ & $\begin{array}{l}154.4 \pm \\
28^{\mathrm{a}} \\
\end{array}$ \\
\hline
\end{tabular}

N.B: The results are presented as means \pm standard error of mean. Values with different superscripts are significantly different while values with the same superscripts are not significantly different at $P<0.05$ 
The other baseline values measured e.g. PCV and WBC as well as clinical assessment was all normal before drug administrations.(see Table 1)

The highest enzyme activity was obtained at the $8^{\text {th }}$ hour for both the enzymes with mean values of $16.7 \pm 2.0$ $(10-23)$ and $7.8 \pm 1.9(4-12)$ IU/L respectively.

The enzyme activities for both groups are statistically significant $(\mathrm{p}<0.05)$ at the $8^{\text {th }}$ hour. AST also showed significantly $(\mathrm{p}<0.05)$ different values at 3,6 and 12 hour compared to the 0 hour (baseline values).

The Tables 1 and 2 also show the mean enzyme activities for ALP, LDH and CK before and after administration of the drugs. All the enzymes have their peak concentration at the $8^{\text {th }}$ hour $(40.8 \pm 18(23=70)$, $63.8 \pm 19.1(44-92)$ and $198.7 \pm 70(123-371)$ IU/L respectively) with slight variations between 8 to 12 hours from the base lines. In the case of $\mathrm{LDH}$ there were significant $(\mathrm{P}<0.05)$ changes at 6,8 , and 72 hours $(184.7 \pm 53.2,198.7 \pm 70.7$ and $155.5 \pm 42.1$ respectively). These hours' correlates with increase and decrease of plasma concentration of halofantrine, however the rise did not correspond to the normally expected rise of LDH as seen in myocardial damage, which usually (peak 24-48 hours). Though these early raise in LDH in these study, however, remains stable until the end of the study (168 hours).

\section{DISCUSION}

The activities of some hepatic and cardiac enzymes in this study, after a single fed of healthy human volunteers were assessed. The results of this study shows that the enzyme activity decreases as the effect of the drug decreases and the peak enzyme activities correlate well the thax of halofantrine as seen in earlier pharmacokinetic studies (Onyeji et al 1998, Bassi PU et al 2004).

The activities of liver transaminases (ALT \& AST), the alkaline phosphatase and cardiac enzymes CK \& LDH were significantly higher compared to baseline values. These values were also high between the $8-12$ hours, which corresponds with the usual peak plasma concentration of halofantrine as seen in literature (Kwabang et al 1984, Milton et al 1985, Watkins et al 1995, Touze JE et al 1996 and Bassi et al 2004).

Halofantrine has a wide inter-individual variability, thus the fluctuation of the enzymes activities as seen in this subjects may be related to the inter individual variations of the oral bioavailability of halofantrine (Bassi et al, 2002 Milton et al; 1989) Sowunmi et al 1998, Eric Monlun 1995, Margretha et al 2004 all has demonstrated significant QTC prolongation in subjects after halofantrine administration. The QTC prolongation is also dose dependent Milton et al 1989. This implies therefore that there may be a higher activity when full dose of the drug is administered.

\section{CONCLUSION:}

In conclusion, this study demonstrate from the results presented that there was peak enzyme level of the various enzymes as the drug reached its peak serum concentration i.e. 6-12 hours and the enzyme activity declined as the effect of the drug weaned off the system. This indicates that changes in the enzyme activities could occur at higher concentration of the drug or after a repeated dosing (it is concentration dependant) as the ECG changes in other studies. Thus it implies that halofantrine is not only cardiotoxic, it is also hepatotoxic, more so assessment of serum levels of this enzymes may have a place in the diagnosis and monitoring of patients with halofantrine toxicity.

\section{Acknowledgement:}

We acknowledge the technical contributions of Mrs Rebecca Gali and Rhoda Genesis of the department chemical pathology, Maiduguri Teaching Hospital. Mr Medugu, Justus Jibrin of Physiology and pharmacology departments assisted in the sampling and analysis. Mrs Gladys (Secretary) Pharmacology and Therapeutics departments help in typing the manuscripts. The contributions of Dr AP Bassi, Dr AH Nggada and Dr DS Mshelia are acknowledged.

\section{REFERENCES}

Afonja O.A.,(1993) Plasma transaminases in healthy Nigerians Nig. J Med. Prac. 25; 33 - 35

Bassi PU, Onyeji CO, Otas EU.,(2004) Effects of tetracycline on the pharmacokinetics of halofantrine in healthy volunteers. 58. 52 / 55.

Briggs $M$ and Briggs $M$ (1974). The Elementary and Metabolism of drugs and toxins. An introduction to xenobiochemistry, Heinemana Medical London, pp 3547

Chatterjee, K.D, (1976). Parasitology, Protozoology and Helminthology. Chatterjee Publishers, Calcutta.

Fasan PO, Kofie B.A Adeleye I, Cook A (1974). Orally Administered Amodiaquine Base suspensions in the Treatment of Acute malaria infections of young children in Nigeria, Trop Med. Nig: 237-243.

Fitch CD, (1983). Mode of Action of Antimalarial drugs in malaria and the red cell. London Pitman pp.222-322

Horton RJ Parr S.N. (1989). Halofantrine, an overview of and Safety, parasitology today (supp): 65-79. 
Karbwang J, Loathavorn P, Na Bagchang K, (1993). Effect of Halofantrine on Electrocardic graphic changes in uncomplicated falciparummalaria patients Lancet 342:8869 Margaretha B, Gilbert LV, Peter D, Antonie S.(2002) Comparism of the cardiac effects of antimalarials $\mathrm{Co}_{-}-\mathrm{Co}$ - artemeter and halofantrine in healhy participants. Am J Trop Med Hyg 66(3), 299-298.

Milton K.A, Edwards G, Ward S.A (1989) Pharmacokinetics of Halofantrine in man,effects of food and dose size. Br J. Clin. Pharmacol 28:71-77

Molta N.B, (1995). Susceptibility of plasmodium faciparum_to malaria drugs in North eastern Nigeria Trans Roy Trop Med Hyg 89:422-425.

Eric Monlun, Le Metayer P,Szwandt S, Neau D, LongyBoursier M, Horton J, Le Bras M,(1995). Cardiac complications of Halofantrine ; a prospective study in 20 patients.Ttans R Soc Trop Med Hyg 89: 430 - 433.

Ngana, E.O, Akanji M.A, and Madu Solomon M.A. (1989). Studies on correlations between chloroquine induced tissue damage and serum enzyme changes in Rats. Experentia, 45: 143-146

Olumese P.E,(1998) Malaria (cerebral malaria) paediatric grand rounds iv Dokita 4-36

Peters W. (1998) Drug resistance in malaria parasites of animals and man Ase. Parasitol, 41. 1-62

Phillips R.S. (2001) current status of malaria and potentials for control Clin Microbiol Rev. 14:208-226

Rathod P.K, McErlean T, per-chieh L (1997). Variations in plasmodium falciparum. Proc Natl Acad. Sci. USA 94:93899393
Robert, K.M, Peter, A.M, Victor W.R, Daryl K.G (1990). Biochemistry of Disease: Harper's Biochemistry $22^{\text {nd }}$ edition. California Lange Medical publication pp.663-679 Salako, L.A, Aderonmu, A.F (1987): In Vitro

Choloquine and Mefloquine Resistant $P$. falciparum in Nigeria Lancet 1:572-573

Sowunmi A, Oduola AMJ (1998). Validity of plasmodium falciparum ex vivo: comparison of the effects of artemether and sulfadoxine pyrimethamine. Eur. J. Clin. Pharmacol. 54: 221-226.

Ter Kuile FO, Dolan G,Nosten F, Edstein MD,Luxermburger C, Phaipun L,ChongsuphajaisiddhiT, Webster,HK, White NJ.,(1993

C) Halofantrine versus mefloquine in treatment of multi=drug resistant falciparum malaria. Lancet

Warhurst DC (2001). A molecular marker for chloroquineresistant falciparum malaria (editorial) New Evgl. J med. 344:299-302

World Health Organisation, (1994), How to investigate drug use in Communities. WHO Geneva

World Health Organisation, (1994), Control Tropical Disease (CTD) Malaria Control, Geneva Switzerland WHO office of information.

World Health Organisation, (1996), Assessment of therapeutic efficacy of Antimalarial drugs for uncomplicated falciparum malaria in areas of intense transmission. WHO Geneva, Switzerland. 